\title{
After the Storm: Party Systems in Southern Europe in the Wake of the Eurocrisis
}

\author{
Višeslav Raos \\ University of Zagreb \\ E-mail: vraos@fpzg.hr
}

Original scientific paper

UDK 329(4-13)

DOI 10.17818/SM/2021/1.2

Paper received: 8. 6. 2021.

Paper accepted: 14. 12. 2021.

\begin{abstract}
Foryears, the countries of Southern Europe have struggled with the consequences of the sovereign debt crisis. Under external pressure they enacted harsh austerity measures which resulted in shaken trust in the European Union, new protest movements and the entrance of new political parties in legislatures and governments. A decade later, this paper poses the question whether the storm of the European sovereign debt crisis has left an impact on Greece, Italy, Portugal, and Spain. The article focuses on changes on the macro-level and analyzes party system changes with the help of data from the CMP/MARPOR dataset. The paper deals with changes in the attitude towards the European Union, the position on the left-right scale (RILE), as well as economic and welfare policy. The analysis has shown a weak decrease in positive attitudes towards the EU in Italy, a moderate leftward shift of the Spanish party system, as well as a moderate decrease in positive attitudes towards the role of the state in the economy in the Greek case. In conclusion, one can say that ten years after the European sovereign debt crisis it is not possible to speak of drastic party system change in Greece, Italy, Portugal, and Spain, and that external pressure has not succeeded in having an impact on the fact that Southern European party systems are, in general, titled towards the left.
\end{abstract}

Key words: Southern Europe, European sovereign debt crisis, Euroscepticism, policy shift, electoral manifestos

\section{Introduction / Uvod}

A decade has passed since the sovereign debt crisis in the European Union and the ensuing Eurocrisis, has seriously shaken politics, economy, and society in Southern Europe. Ten years later, we should ask ourselves what impact of "Europe's perfect storm" (Müller, 2012) can we observe in Greece, Italy, Portugal, and Spain. This paper offers an analysis of party policy change in Southern Europe after the sovereign 
debt crisis in Eurozone countries and austerity measures mandated by the so-called European troika (European Commission (EC), European Central Bank (ECB), and the International Monetary Fund (IMF)). External pressure has enticed governments in Lisbon, Madrid, Rome, and Athens to undertake unpopular measures, cabinets have fallen, young and old has taken to the streets, vocal challenger parties and movements have entered the political arena and shaken up the status quo. Yet, it remains to be seen, and empirically examined, whether we can indeed speak of a transformation on party system level. Recent research by Branco et al. (2019) has uncovered "structural policy reversal" going hand-in-hand with partial endurance of austerity measures enacted during the years of external, EU-mandated conditionality. In addition, a comparison of Italy and Portugal has shown that government responsiveness to the needs of core electorates has led to reversal of crisis-management policy, albeit with varying intensity across different policy areas (Afonso and Bulfone, 2019). This paper seeks to further test this proposition by looking at the macro-level, the level of party systems and their main ideological underpinnings, measured by common policy positions evident from party electoral manifestos.

\section{Austerity, Anger, and Alternation / Štednja, ljutnja i izmjenjivanje}

The European sovereign debt crisis was triggered in late 2009 when it was revealed that the government in Athens could not meet its financial obligations towards international creditors. Next year, the crisis spread to other parts of the eurozone and started threatening the whole Union, both politically and economically. The response that came from the corridors at Berlaymont was direct or indirect pressure from the European troika on highly indebted eurozone member states, most notably those in the Mediterranean area, to enact strict fiscal consolidation measures (Perez and Matsaganis, 2018: 192). Heavy-handed budgetary cuts had a pro-cyclical effect, plunging their national economies into recession, resulting in mass unemployment (especially among the youth, both highly educated and less so). High joblessness gave rise to increased emigration levels that matched even those in post-communist Europe (see more in MIDEM, 2020). In addition, comparisons of effects of austerity measures undertaken in Southern Europe have shown that inequality has increased in Greece, Italy, and Spain, with the notable exception of Portugal (Perez and Matsaganis, 2018: 203). Finally, harsh austerity provoked anger and resentment, resulting in various protest movements, such as the indignados of Spain (cf. Antenas, 2017) or the increased trade union mobilization in Greece, as people vented out their frustration at sudden loss of disposable income.

Although the aftermath of the sovereign debt crisis in Southern Europe is usually associated with harsh measures of budget cuts that involved shrinking of the welfare state, one can also find opposite examples, such as welfare expansion under the short-lived (2014-2016) Renzi government in Italy, which testify to the fact that external measures could not always trump domestic policy priorities (cf. Vesan and Ronchi, 2019: 390). Also, this could hint at the notion of "policy reversal" or the idea that nothing much has, indeed, changed, with the Eurocrisis.

After the sovereign debt crisis and the bailout and fiscal stabilization programs supervised by the Troika, there came deep electoral changes (Bosco and Verney, 
2012). Some authors (Freire, Lisi, Andreadis, and Leite Viegas, 2014) have pointed out that the sovereign debt crisis in Southern Europe has turned from an economic crisis into a political legitimacy crisis, which had tremendous impact on political parties and their ability to adequately represent citizens and sustain voter support. Thus, changes in patterns of party competition and increases electoral volatility have ultimately led to structural changes in government types in the Mediterranean EU member states, including technocratic cabinets, oversized coalitions, and cabinets led by erstwhile pariah parties representing the ideological fringe (cf. Bosco and Verney, 2016). One of the most striking features of this shift was parliamentary and executive cooperation of previous fierce competitors - mainstream social democratic and radical left parties (Balampanidis, Vlastaris, Xezonakis, and Karagkiozoglou, 2019).

Since the outbreak of the European sovereign debt crisis in 2009, there has been a succession of short-lived governments in Southern Europe. According to longitudinal data gathered by the ParlGov database (Döring and Manow, 2021), Greece has seen five elections since 2009, three of which were snap elections, and was led by a total of eight different cabinets, two of which were caretaker governments. The same data source reveals that Italy has, in contrast, held two parliamentary elections since the onset of the crisis, followed by seven cabinet, one of which (led by Mario Monti) was a caretaker government. Further, Portugal held one snap and two regular elections, resulting in four cabinets. Finally, Spain has held five elections since the European sovereign debt crisis, out of which four were early elections, and has had seven cabinets, three of which were caretaker governments. Yet, in the Spanish case, one can ascribe this rising instability to internal matters (the Catalan question), rather than to the external stress produced by the financial crisis.

The downfall of traditional, mainstream political forces and the entry of once fringe left-wing parties (Greece, Portugal) or new, challenger parties (Five Stars Movement, Podemos) into government were closely linked with increased citizen resentment at the institutions of the European Union, largely seen as culprits for their material hardships during the recession and recovery years of the early to mid-2010s.

According to research done a fewyears after the Eurocrisis, the prolonged bailout and austerity measures imposed by the Troika exacerbated citizen attitudes towards the European Union in Greece and Portugal (Freire, Teperoglou, and Moury, 2014). Yet, popular Euroscepticism in Greece was of a more affective and volatile, than substantial nature, and did not translate into serious challenges towards Hellenic membership in the monetary union or the Union itself (Clements, Nanou, and Verney, 2014).

In Italy, EU-mandated austerity and the question of national vs. supranational authority has produced a new pro/anti-EU cleavage that transcends previous EUrelated contentious issues, such as migration and economy (Giannetti, Pedrazzani, Pinto, 2017: 35). Further, in the Italian case, one could, according to newest research, observe a congruence between a Eurosceptic shift among party elites and among voters (Conti, Marangoni, and Verzichelli, 2020).

Spain has also seen a rise in Eurosceptic attitudes, yet this was largely not a result of a dramatic shift of the Spaniards' views of the European Union, but a reflection of a deep political and institutional crisis triggered by the Catalan question, i.e., the rise of the pro-independence movement and the 2017 referendum (cf. RealDato and Sojka, 2020). 
In Portugal, Euroscepticism gained momentum as the far-left came into the spotlight during the sovereign debt crisis, yet recent studies could not confirm a structural realignment of party politics in this Atlantic-Mediterranean country regarding the attitude towards the European Union (Lisi, 2020). Yet, Portugal was the only of our four analyzed cases that did not experience a major re-alignment of the components of its party system, that is to say, no challenger party succeeded in drastically changing the pattern of party competition. Indeed, an unlikely cooperation of socialists (PS) and communists (PCP) managed to meet external expectations of fiscal restraint with domestic needs of welfare policy (cf. Fernandes, Magalhães, and Santana-Pereira, 2018).

However, a new study using the Euromanifestos database has shown that the European sovereign debt crisis has not had a significant impact on the structuring of the pro/anti-EU dimension of party competition in Southern Europe (Schäfer, Popa, Braun, and Schmitt, 2021). In addition, Teperoglou and Belchior (2020), also using the Euromanifestos database in their new research, concluded that rising Eurosceptic attitudes were contextually linked to the Eurocrisis and of a passing nature, while anti-EU stances in the Greek and Italian cases possessed a more lasting character.

Bearing all this in mind, we point out to the uncertainty whether all these processes can truly be regarded as signs of a complete turnaround in party policy and meta-nature of the party system in the Greek, Italian, Spanish, and Portuguese cases.

\section{Research Questions / Istraživačka pitanja}

This paper tries to find an answer to the question of party system change in Southern Europe after the Eurocrisis (RQ0). In other words, the aim of the paper is to detect whether the Eurocrisis has had an impact on policy positions on key issues, such as the European Union, the overall left-right position, economic policy and welfare policy. The paper first tests whether there have been substantial changes in attitudes towards the European Union (RQ1). Then, it looks for shifts in the position on the left-right (RILE) scale (RQ2). Further, it analyzes changes in economic (RQ3) and welfare (RQ4) policy. The four auxiliary research questions are approached on three different levels. The first level is the regional level, i.e., Southern Europe. The second one deals with differences between party families in the whole region, while the third one pertains to differences between the four countries.

\section{Data and Methods / Podaci i metode}

This study relies on data obtained from the Comparative Manifesto Project (CMP/ MARPOR) dataset; an international collaborative database of party electoral manifestos structured in quasi-sentences ${ }^{1}$ and coded by national expert teams according to a common coding scheme. The latest, 2020 version was used for this study (Volkens et al., 2020a).

\footnotetext{
${ }^{1}$ In quantitative text analysis, quasi-sentences are the smallest unit of text that can be interpreted as one statement, in the case of the manifesto dataset, this would mean one policy statement.
} 
For the purpose of this paper, we subset the dataset to isolate cases from our four Southern European EU member states of interest, Greece, Italy, Portugal, and Spain. The time span for the analysis was set to include cases after 1975, as to account for the fact that Greece, Portugal, and Spain experienced democratic transition (cf. Linz and Stepan, 1996) during the 1970s and that after the aforementioned year we can synchronously compare all four countries. Since election cycles naturally vary from country to country, the actual time span for the manifestos included in the subset ranges from April 1976 (Portugal) to November 2019 (Spain). The total number of cases (individual party electoral manifestos) included in the study was 491.

When using data from the CMP/MARPOR dataset, this paper follows the assumption, established by Lowe et al. (2011), that party electoral manifesto data should be understood in light of clear-cut oppositional policy positions (described by "left" and "right" categories as proxies for ideological oppositions, not necessarily "leftwing" and "right-wing" in the sense of common parlance), rather than the common approach which looks at salience of a given topic (i.e., variable in the CMP/MARPOR dataset). In this fashion, we can analyze manifesto data by establishing policy ranges that are derived from ratios between "left-wing" and "right-wing" or "negative" and "positive" or "disproving" and "affirmative" positions on a given topic. Thus, a party's position on e.g., the European Union is a ratio of all positive and negative statements about the EU in its party manifesto. This ratio is log-transformed, i.e., normalized with the help of natural logarithms, as suggested by Lowe et al. (2011, 30).

Therefore, the four scales used in this analysis are logit_EU (Lowe et al., 2011), which measures party attitudes on the European Union, logit_rile; the logtransformed version of the left-right (RILE) index originally described by Laver and Budge (1992) which places party manifestos on a unidimensional left-right scale; stateconomy as a measure of state involvement in the economy (Benoit and Laver, 2007); and stateservices, a scale that measures attitudes in welfare state policy (Lowe et al., 2011). In this paper, the original stateservices scale was expanded to include the 503 Equality: Positive CMP/MARPOR code (see Table 1 for a detailed description of codes behind each of the scales). 
Table 1. CMP Additive Scales / Tablica 1. CMP Aditivne ljestvice

\begin{tabular}{|c|c|c|c|c|}
\hline \multirow{2}{*}{$\begin{array}{c}\text { Policy } \\
\text { Dimension }\end{array}$} & \multicolumn{2}{|c|}{ CMP Codes } & \multirow{2}{*}{ Source } & \multirow{2}{*}{ Scale } \\
\hline & "left" position & "right" position & & \\
\hline $\begin{array}{l}\text { Attitude } \\
\text { Towards the } \\
\text { European } \\
\text { Union }\end{array}$ & $\begin{array}{l}108 \text { European Integration: } \\
\text { Positive }\end{array}$ & $\begin{array}{l}110 \text { European Integration: } \\
\text { Negative }\end{array}$ & $\begin{array}{l}\text { Lowe } \\
\text { et al., } \\
2011\end{array}$ & logit_EU \\
\hline $\begin{array}{l}\text { Left-Right } \\
\text { Index }\end{array}$ & $\begin{array}{l}103 \text { Anti-Imperialism: Anti- } \\
\text { Colonialism } \\
105 \text { Military: Negative } \\
106 \text { Peace: Positive } \\
107 \text { Internationalism: Positive } \\
202 \text { Democracy: Positive } \\
403 \text { Market Regulation: Positive } \\
404 \text { Economic Planning: Positive } \\
406 \text { Protectionism: Positive } \\
412 \text { Controlled Economy: } \\
\text { Positive } \\
413 \text { Nationalization: Positive } \\
504 \text { Welfare State Expansion: } \\
\text { Positive } \\
506 \text { Education Expansion: } \\
\text { Positive } \\
701 \text { Labor Groups: Positive }\end{array}$ & $\begin{array}{l}104 \text { Military: Positive } \\
\text { 201 Freedom and Human } \\
\text { Rights: Positive } \\
203 \text { Constitutionalism: } \\
\text { Positive } \\
\text { 305 Political Authority: } \\
\text { Positive } \\
401 \text { Free Enterprise: Positive } \\
402 \text { Incentives: Positive } \\
407 \text { Protectionism: Negative } \\
414 \text { Economic Orthodoxy: } \\
\text { Positive } \\
505 \text { Welfare State } \\
\text { Limitation: Positive } \\
601 \text { National Way of Life: } \\
\text { Positive } \\
603 \text { Traditional Morality: } \\
\text { Positive } \\
605 \text { Law and Order: Positive } \\
606 \text { Social Harmony: } \\
\text { Positive }\end{array}$ & $\begin{array}{l}\text { Laver } \\
\text { and } \\
\text { Budge, } \\
1992\end{array}$ & logit_rile \\
\hline $\begin{array}{l}\text { State } \\
\text { Involvement } \\
\text { in the } \\
\text { Economy }\end{array}$ & $\begin{array}{l}403 \text { Market Regulation: Positive } \\
404 \text { Economic Planning: Positive } \\
406 \text { Protectionism: Positive } \\
412 \text { Controlled Economy: } \\
\text { Positive } \\
413 \text { Nationalization: Positive } \\
504 \text { Welfare State Expansion: } \\
\text { Positive } \\
506 \text { Education Expansion: } \\
\text { Positive } \\
701 \text { Labor Groups: Positive }\end{array}$ & $\begin{array}{l}401 \text { Free Enterprise: Positive } \\
402 \text { Incentives: Positive } \\
407 \text { Protectionism: Negative } \\
414 \text { Economic Orthodoxy: } \\
\text { Positive } \\
505 \text { Welfare State } \\
\text { Limitation: Positive }\end{array}$ & $\begin{array}{l}\text { Benoit } \\
\text { and } \\
\text { Laver, } \\
2007\end{array}$ & stateconomy \\
\hline $\begin{array}{l}\text { Welfare } \\
\text { State Policy }\end{array}$ & $\begin{array}{l}503 \text { Equality: Positive* } \\
504 \text { Welfare State Expansion: } \\
\text { Positive } \\
506 \text { Education Expansion: } \\
\text { Positive }\end{array}$ & $\begin{array}{l}505 \text { Welfare State } \\
\text { Limitation: Positive } \\
507 \text { Education Limitation: } \\
\text { Positive }\end{array}$ & $\begin{array}{l}\text { Lowe } \\
\text { et al., } \\
2011\end{array}$ & stateservices \\
\hline
\end{tabular}

Source: Adapted after Lowe et al., 2011: 136, 139-140. For a comprehensive description of individual codes, see the CMP/MARPOR codebook (Volkens et al., 2020b).

* Added in this study.

We calculated the logit_rile values with the built-in feature (logit_rile scale) of the manifestoR package (see Lewandowski, 2016: 13). In the same vein, we constructed the other composite variables constructed around log-transformed binary oppositions (see Lowe et al., 2011: 136-137).

Party manifestos in the four examined countries were grouped in decades (1970s, 1980s, 1990s, 2000s, and 2010s), so as to enable longitudinal analysis of policy change on party system level. Preliminary tests of normality of data distribution with the help of the Shapiro-Wilk test and density plots have shown that parts of our dataset significantly deviated from a Gaussian distribution. In addition, the number 
of cases (party manifestos) in some of the subgroups (decades) was below 15, a number which is deemed a minimal requirement for the usage of parametric tests with non-normally distributed data.

Taking all this into account, we opted for the usage of non-parametric tests for our analysis of policy change over time (between decades). Since we focus primarily on the expected change between the 2000s ("before the storm") and the 2010s ("after the storm"), we present figures (box plots) for all decades after 1975, yet calculate differences just for these two decades, using the non-parametric equivalent of a $t$-test, namely the Wilcoxon-Mann-Whitney test. For statistically significant results, we also calculate Wilcoxon effect size $(r)$ to determine the actual impact of the observed change in median policy positions.

For each of the four scales, we first look at secular changes, i.e.,whether the distribution for a given party system has shifted in a certain direction. Then, we look at possible changes in the ideological spread of a party system, by inspecting the interquartile ranges for each of the decades. Finally, we assess the differences in median (since we are using a non-parametric test for our analysis) values for the last two decades, to account for the expected systemic changes in the wake of the sovereign debt crisis. The descriptive statistics for the four scales are given in Tables 2 to 5.

\section{Analysis and Discussion / Analiza i rasprava}

\section{Attitude Towards the European Union / Stav prema Europskoj uniji}

Research on Euroscepticism in Southern Europe, discussed in the previous sections, often describes a major anti-EU shift among party elites and voters in the Mediterranean after the sovereign debt crisis. Yet, figures derived from the CMP/ MARPOR dataset, which can be regarded as indicative of party elite opinions (since electoral manifestos project what parties want to think of themselves and present to the voters, and not necessarily what they might do once in government or what their voters expect them to do) paint a somewhat different picture.

Overall, the region of Southern Europe has had stable, pro-EU median values from 1970s until today. Yet, there was a significant shift towards less pro-EU values between the 2000s and 2010s. However, this shift had only a small effect size ( $r=0.14)$. Regarding the four major party families in the region (by the number of data points, i.e., electoral manifestos present in the dataset), no statistically significant changes could be detected.

In Greece, we can observe pro-EU median values starting from the 1970s up until today, with the median logit_EU value dropping to zero during the 2000 s. The interquartile range decreased from the 2000 s to the 2010 s, from 2.09 to 1.879 , while the span between extreme (min and max) values increased. However, the change between the 2000s and the 2010s is not statistically significant. The Italian party system has been firmly rooted around pro-EU values for decades. Yet, when we compare the pre-Eurocrisis and post-Eurocrisis decade values, we can observe a statistically significant move towards less pro-EU values, with the median dropping a whole point, from -1.105 to -0.172. However, for this observed change in attitude towards the European Union in the Italian party system, only a small effect size 
$(r=0.27)$ was detected. In the case of Portugal, we can speak of somewhat less proEU median values on party system level than for the rest of the Mediterranean four. The interquartile range has increased from 2.107 to 2.248, and the median moving from 0 (central point on the logit_EU scale) to 0.154. Nevertheless, no statistically significant change could be detected between the respective 2000s and 2010s periods. Finally, the Spanish party system exhibited the most stable attitudes towards the European Union, with very small changes in both median values and interquartile ranges over the decades. The Eurocrisis did not have a statistically significant effect, thus no meaningful change was observed for the last two decades. One can conclude that despite research that points to passing or more durable rise in Eurosceptic values in Southern Europe, on a systemic level, one can hardly speak of any remarkable change. In this regard Italy, with its two strong Eurosceptic parties, the Lega (formerly Lega Nord) and the Five Star Movement (M5S), represents an exception. In conclusion, only in Italy can we speak of a general movement in EU attitudes that occurred between the onset of the sovereign debt crisis and present day. This shift towards less pro-EU values was, however, of a rather weak nature, as testified by the small effect size that was obtained for the Wilcoxon test.

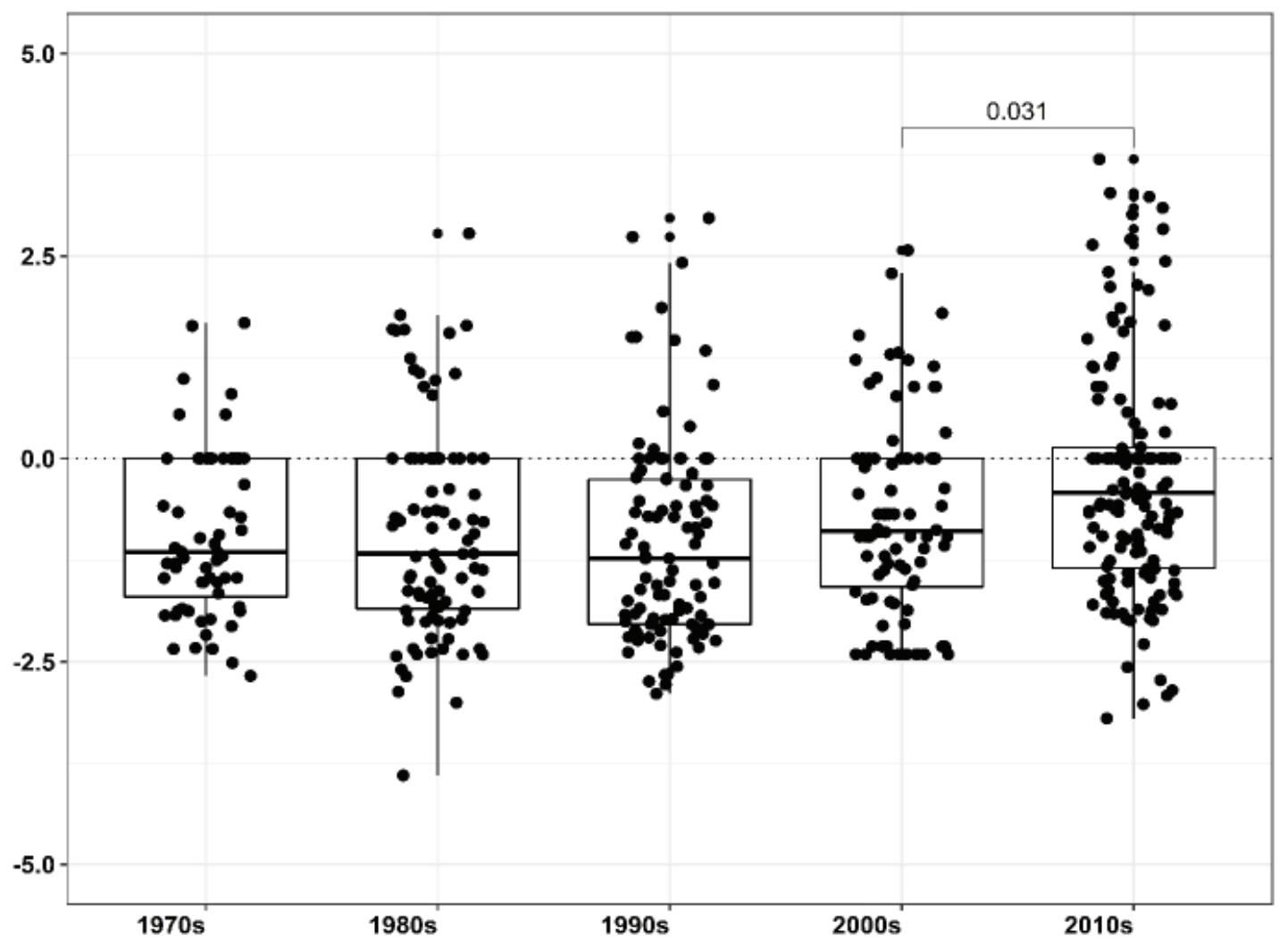

Figure 1. EU Policy, Southern Europe / Slika 1. EU politika, Južna Europa 

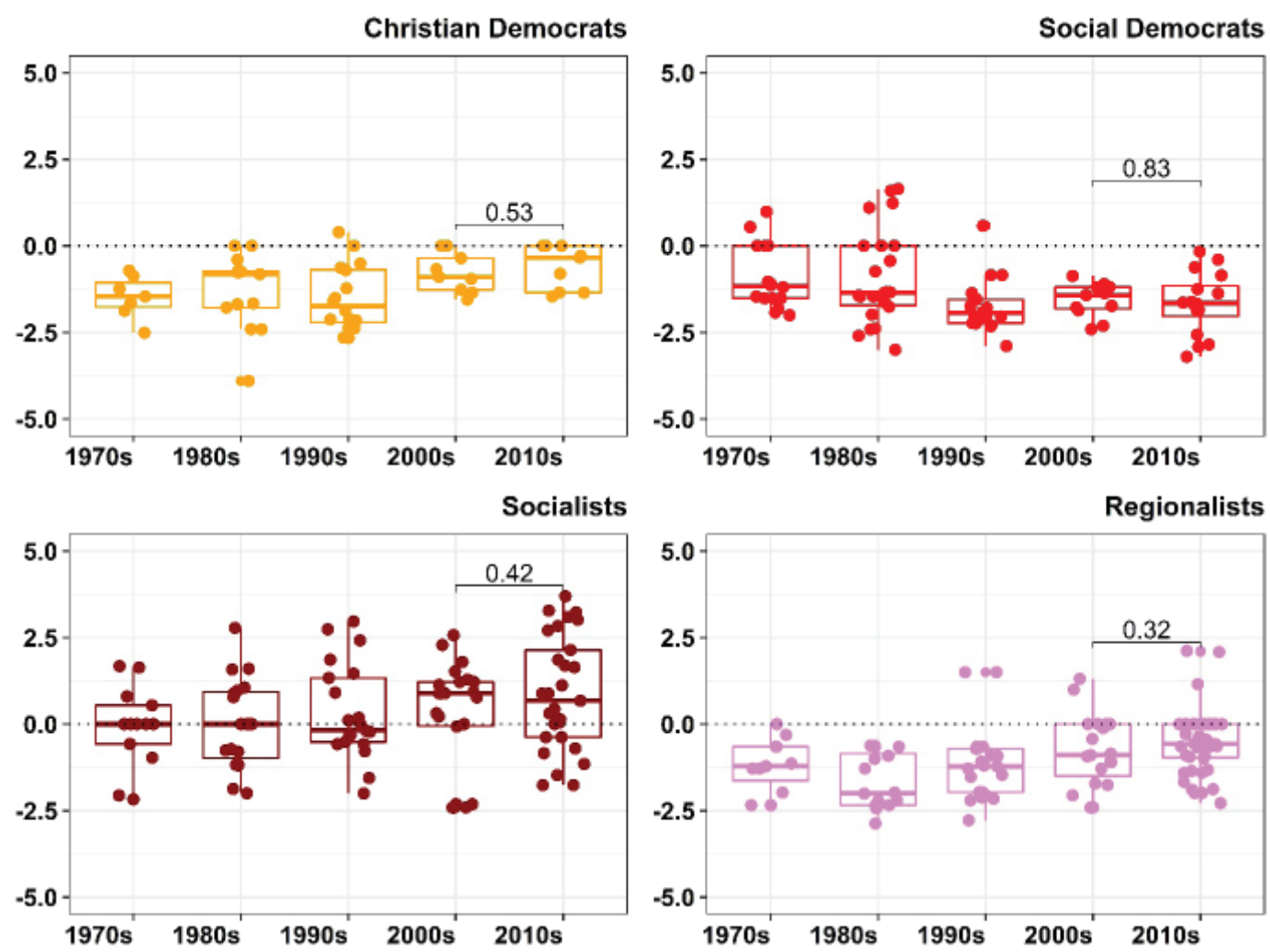

Figure 2. EU Policy by Major Party Family, Southern Europe / Slika 2. EU politika velikih stranačkih obitelji, Južna Europa
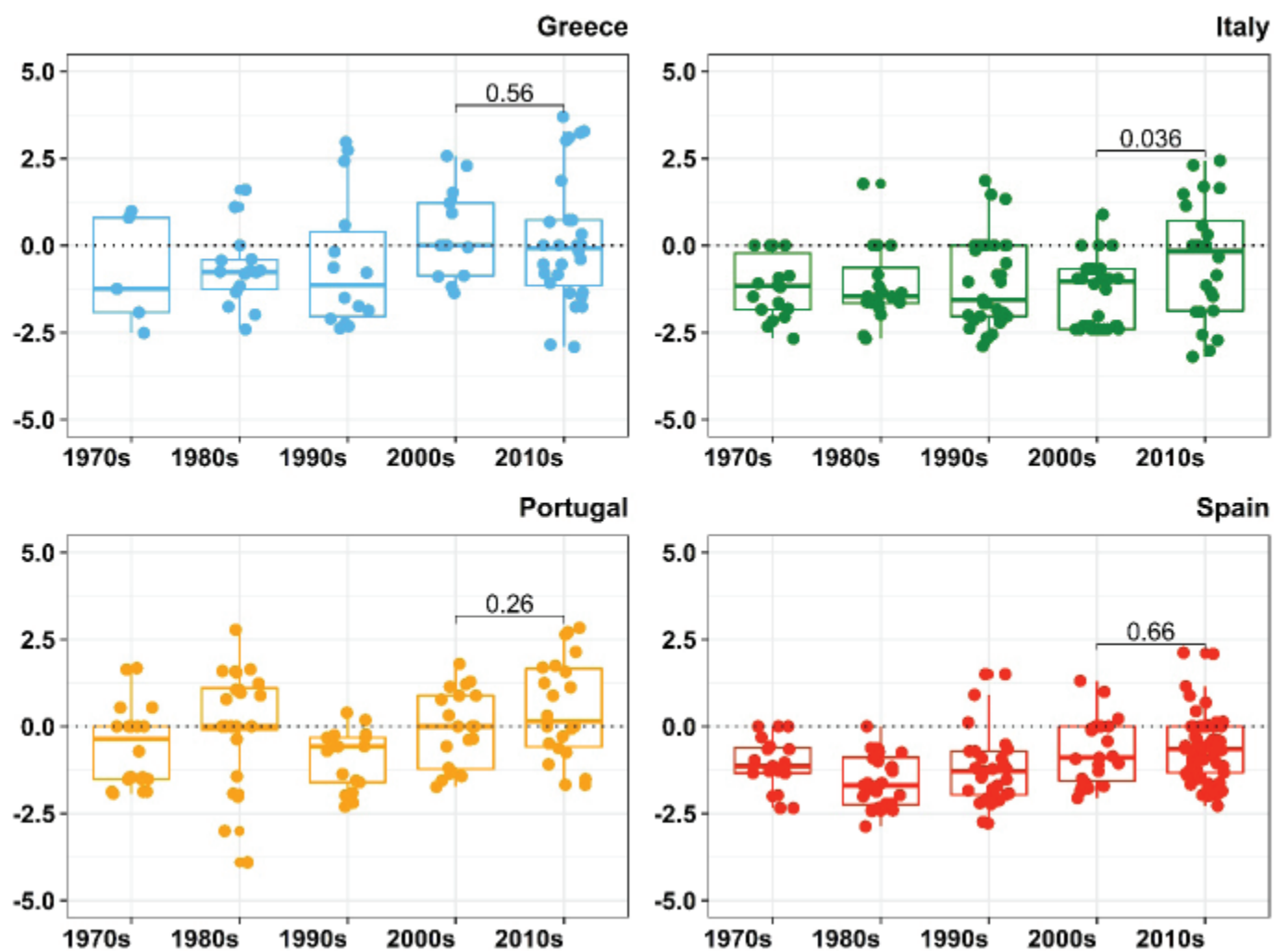

Figure 3. EU Policy by Country, Southern Europe / Slika 3. EU politika po zemljama, Južna Europa 


\section{Position on the Left-Right Scale / Pozicioniranje na ljestvici lijevo-desno}

The overall position of Southern European party systems has shifted somewhat to the left between the 2000s and the 2010s. Again, the effect of this shift was small $(r=0.17)$. This shift was driven by the move of socialist parties further to the left, with an observed moderate effect of this change $(r=0.31)$.

The rather unusual far-right outliers for the Greek party system in the 2000s pertain to the Greek Communist Party (KKE), an orthodox Marxist-Leninist party with underpinnings of social conservatism. Some researchers have proposed alternative measures to the classical CMP/MARPOR approach in order to compensate for sometimes curious ideological misplacements of Greek political party manifestos (see Dinas and Gemenis, 2010), yet this paper already accounts for possible failings of CMP/MARPOR data by using the log ratio approach suggested by Lowe et al. (2011).

Otherwise, we can observe an ideologically very stable party system in Greece, with minimal changes in interquartile ranges and median logit_rile values from the 1970 s to the 2010 s (Figure 6). The ideological spread has somewhat widened between the 2000s and the 2010s, while the median values has slightly moved closer to the center (zero), from 1.02 to 1.473 , respectively. However, no statistically significant change could be observed. In Italy, the median values were very close to center (zero) values yet moved slightly to the right (plus values on the logit_rile scale) during the 1990s and the rise of Silvio Berlusconi's Forza Italia. During the 2000s, one could observe a widening of the ideological spread (IQR jumped from 0.626 to 2.087), with the closing of the ideological spread of the party system after the European sovereign crisis, dropping to 0.815 . However, the change in median logit_rile values between the "pre-storm" and "after-storm" period could not yield statistically significant results. For the Portuguese party system, a visual inspection reveals a very slight left-wing shift over the years and broader ideological spreads since the 2000s. In the 2010s, the interquartile range, here interpreted as the ideological spread of a party system, decreases somewhat, dropping from 1.24 to 1.042. Finally, in Spain we can observe a party system which is titled to the left. The ideological spread was particularly narrow during the 1990s and the 2000s, and then increased after the sovereign debt crisis. In addition, for the change in the placement on the left-right scale (RILE) in the Spanish party system, a small effect size $(r=0.27)$ was detected. Thus, after the Eurocrisis, the Spanish party system became even more left-wing, with a median value of -1.14 , but also more ideologically broad, with the interquartile range of 1.143. 


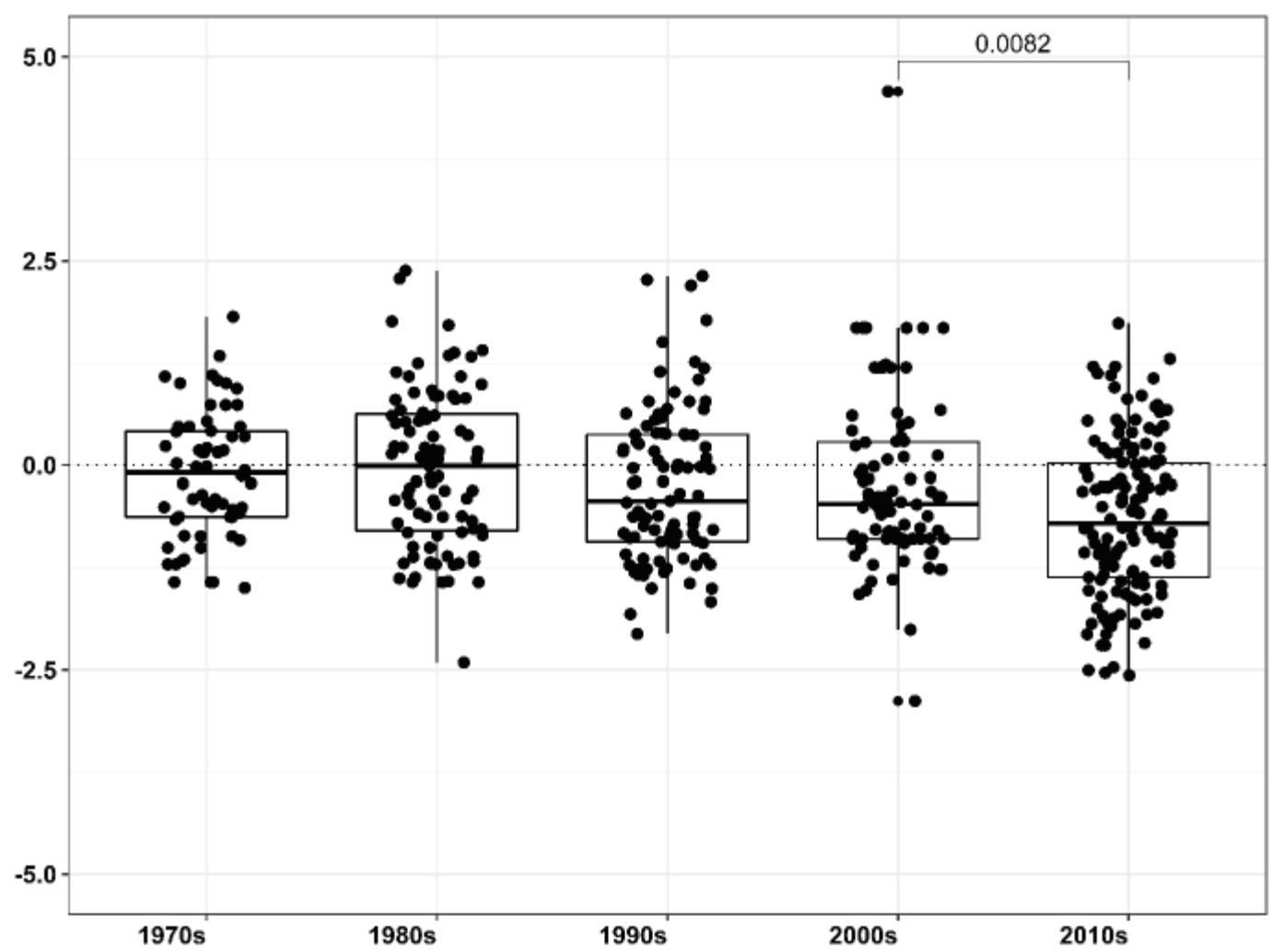

Figure 4. Left-Right Index, Southern Europe / Slika 4. Indeks lijevo-desno, Južna Europa

Christian Democrats
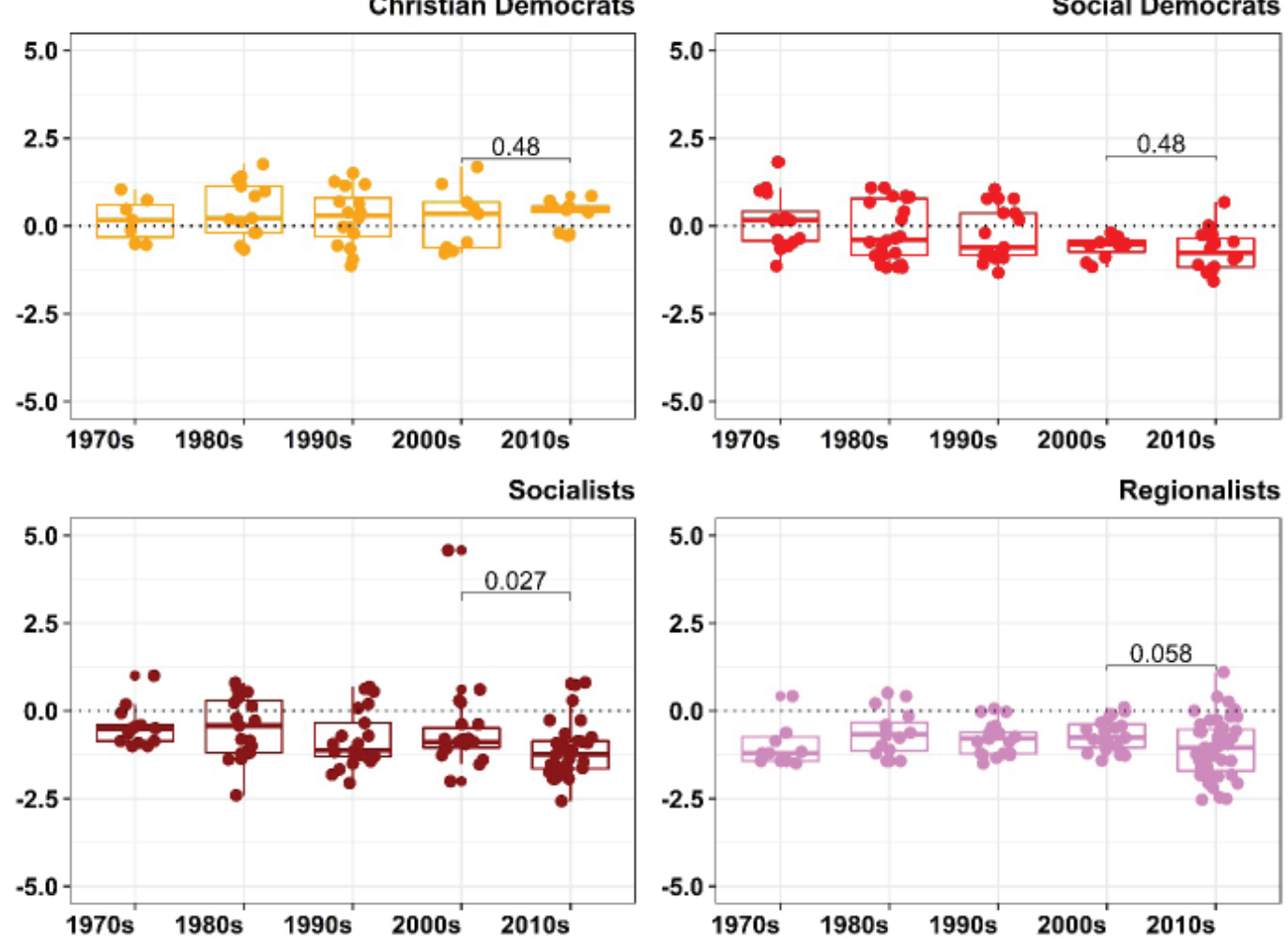

Figure 5. Left-Right Index for Major Party Families, Southern Europe / Slika 5. Indeks lijevo-desno za velike stranačke obitelji, Južna Europa 

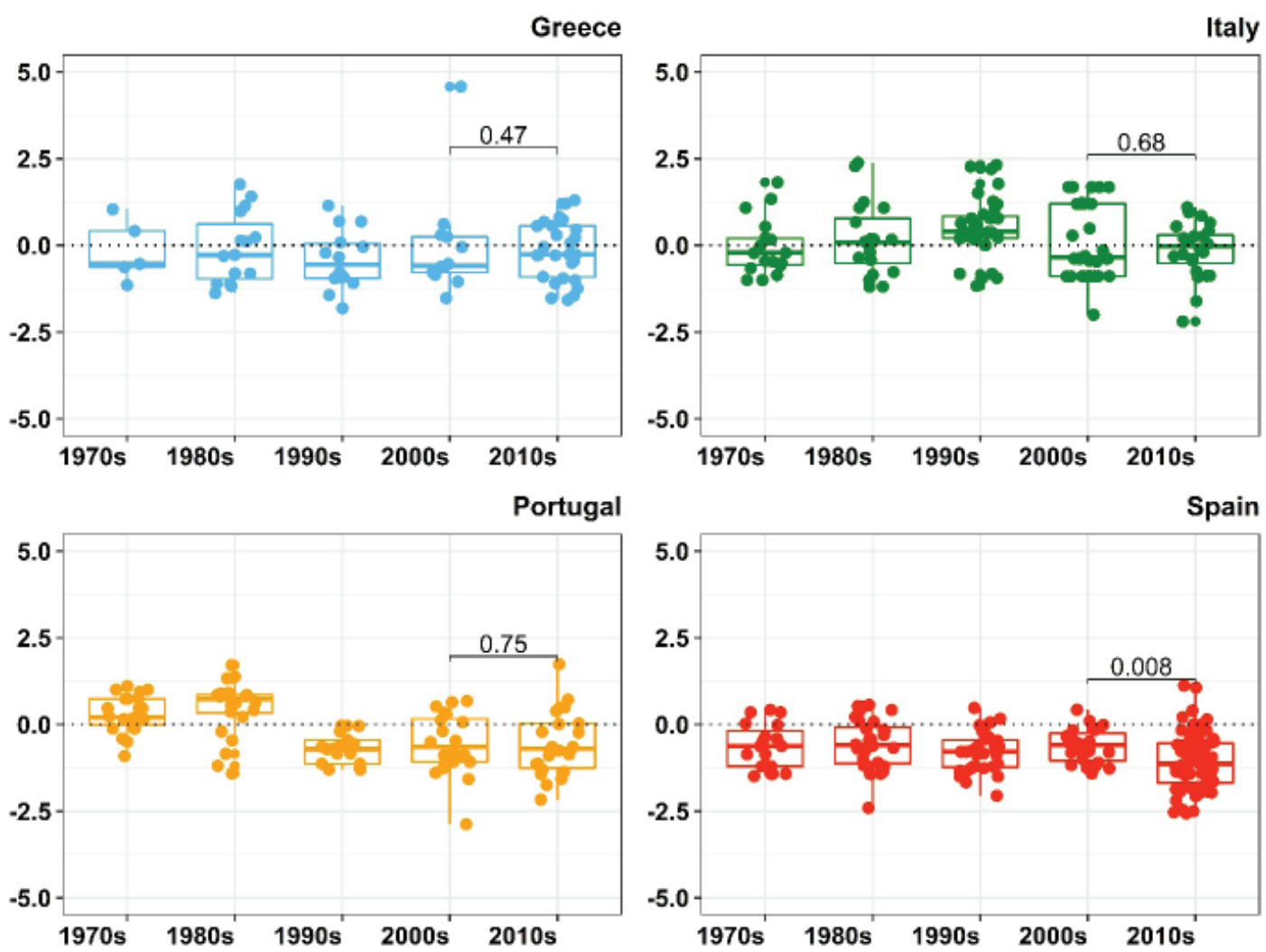

Figure 6. Left-Right Index by Country, Southern Europe / Slika 6. Indeks lijevodesno po zemljama, Južna Europa

\section{Economic Policy / Gospodarska politika}

Regarding economic policy, i.e., the attitude towards state involvement in the economy, the reader should be reminded that negative values represent state interventionism, while positive values stand for laissez-faire economic policy. On the level of the whole region, there were no significant changes between the 2000s and the 2010s. By the same token, on the level of party families, no meaningful changes could be reported.

In Greece, we could observe that on the party system level, more interventionist attitudes prevailed throughout the whole analyzed period. The ideological spread on this issue was relatively high, and since the 1990s, one could note a push towards more left-wing attitudes. However, when we compared the decade before the European sovereign debt crisis and the decade following it, we could detect a moderate effect size $(r=0.33)$ for the change in attitudes towards the level of state involvement in the economy. In other words, a statistically significant change towards less interventionist economic policy was detected (from a median of -2.137 to -0.951 ), with a moderately strong effect. In contrast, in the other cases, there were no statistically significant changes to be observed for the "pre-storm" and "post-storm" periods. 


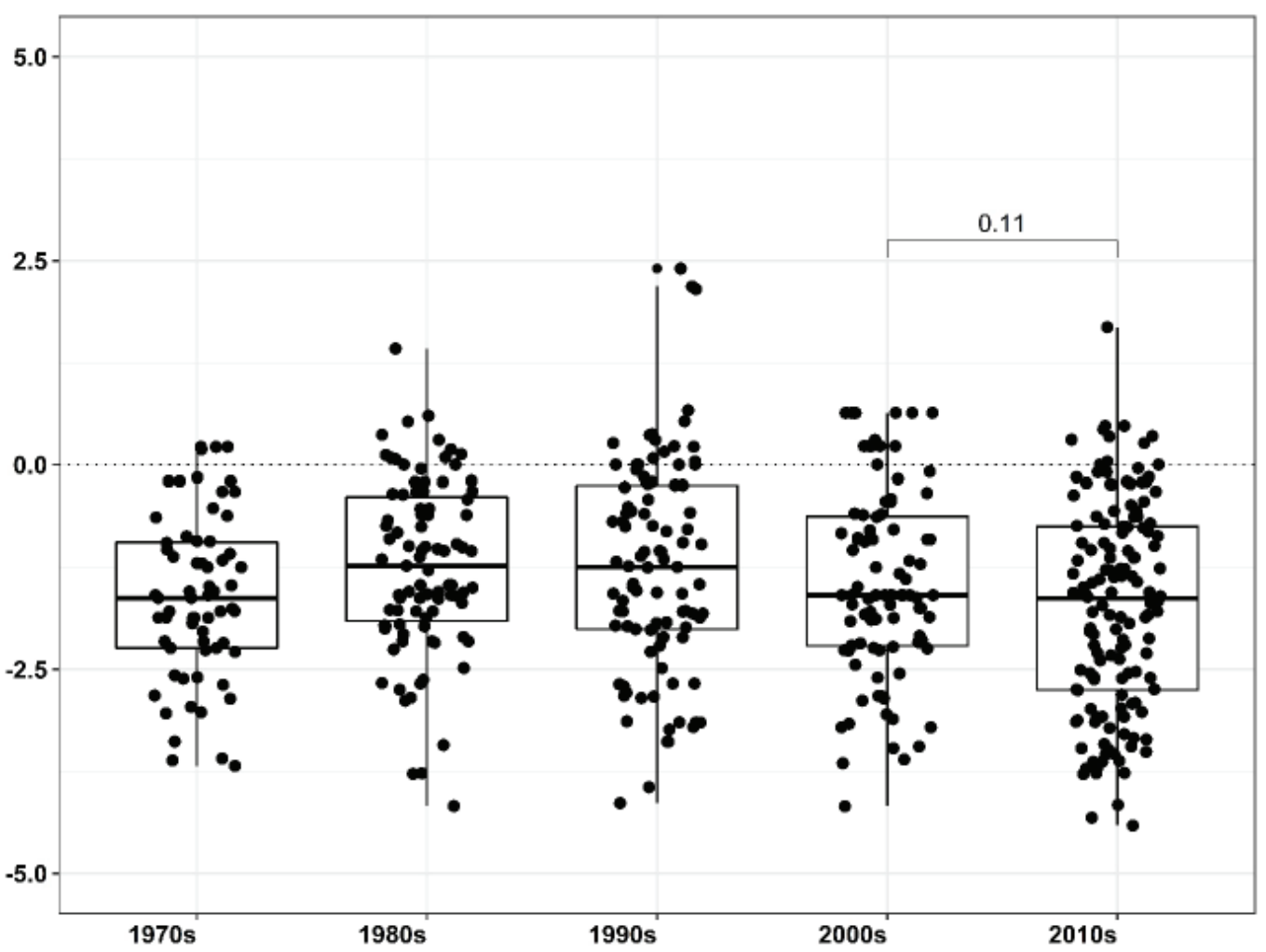

Figure 7. Economic Policy, Southern Europe / Slika 7. Gospodarska politika, Južna Europa
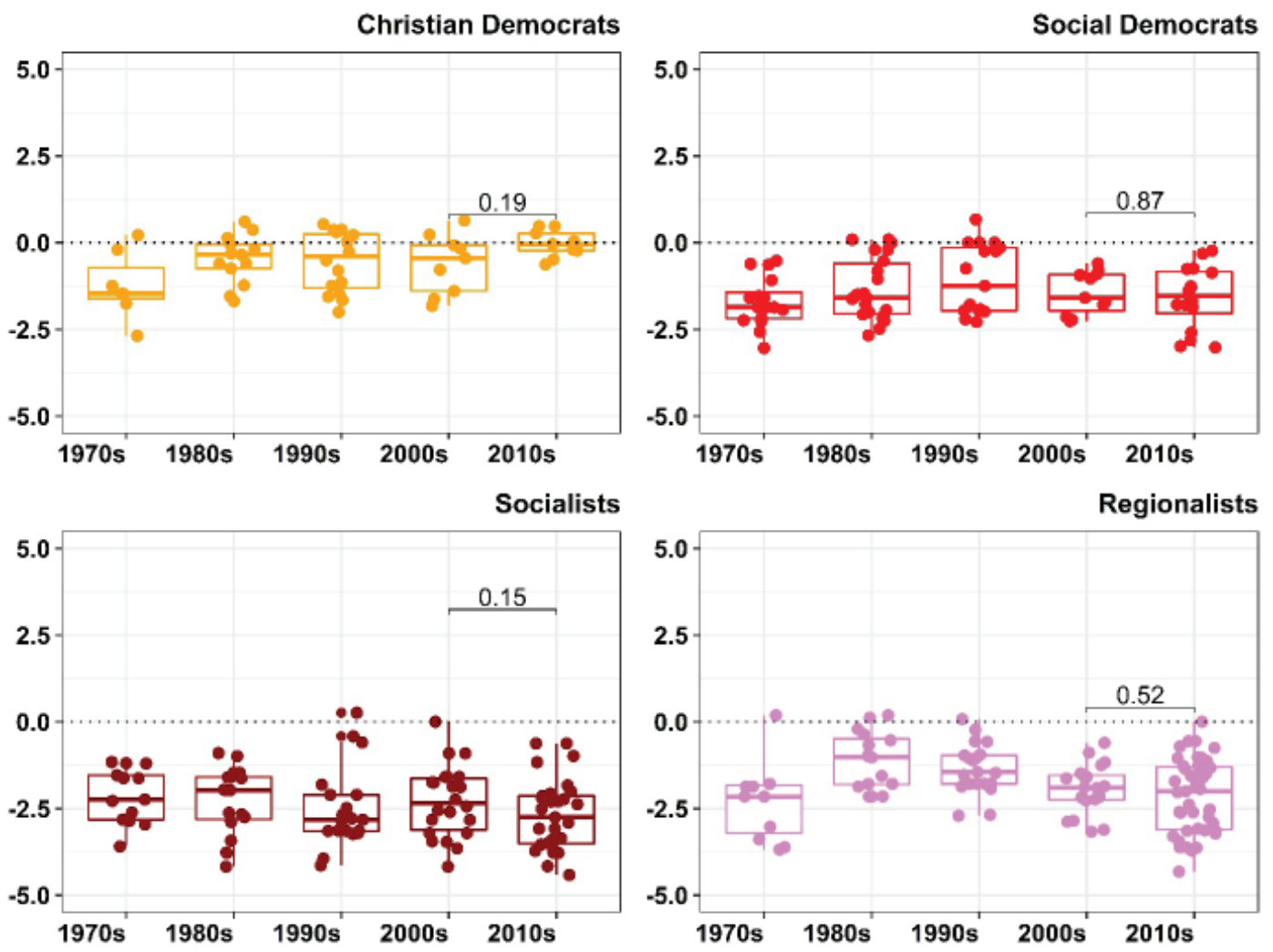

Figure 8. Economic Policy of Major Party Families, Southern Europe / Slika 8. Gospodarska politika velikih stranačkih obitelji, Južna Europa 

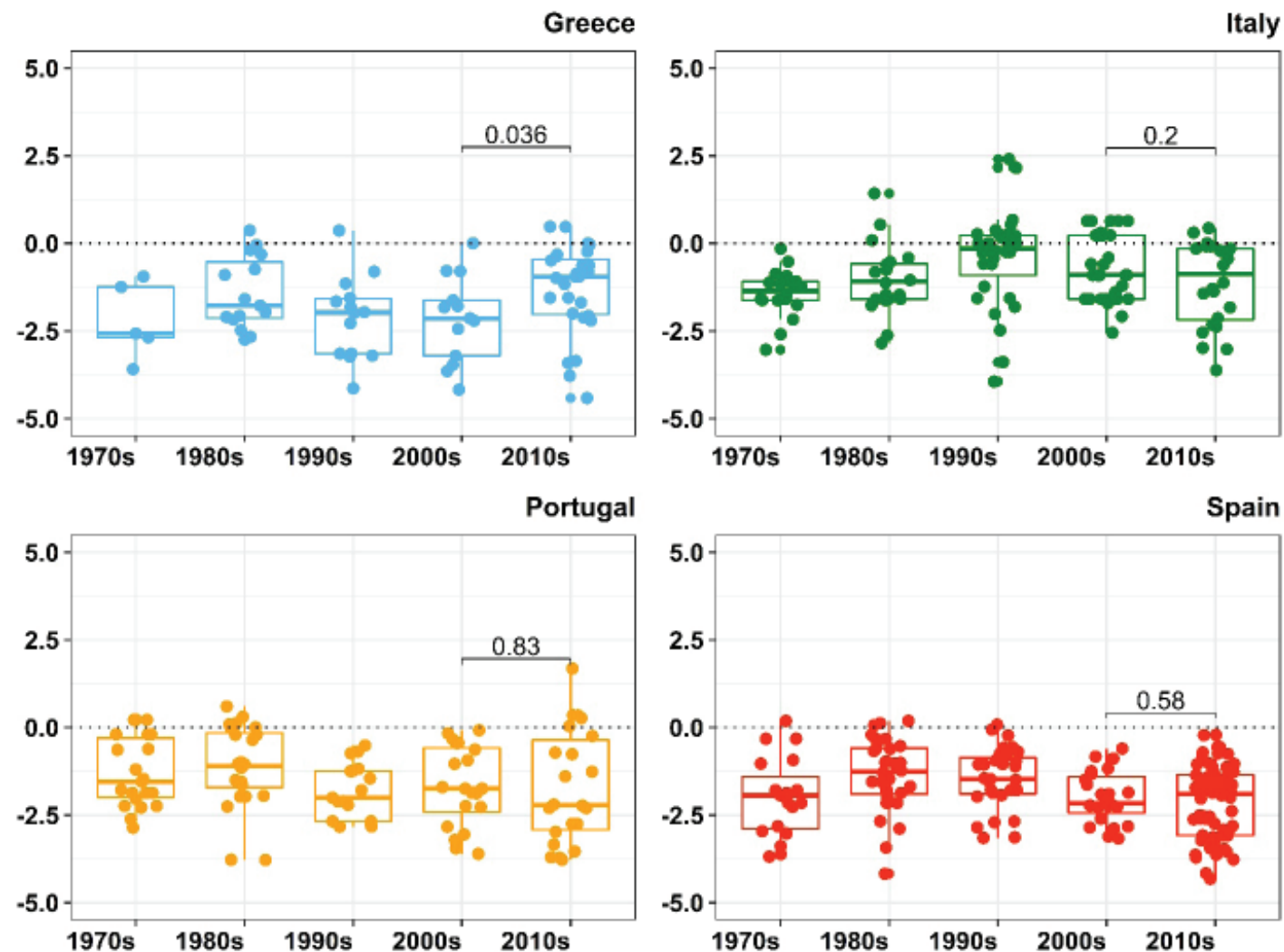

Figure 9. Economic Policy by Country, Southern Europe / Slika 9. Gospodarska politika po zemljama, Južna Europa

In Italy, just like with the left-right index, one could detect a move towards more centrist positions, yet after that, we can see a renewed left-wing trend. The ideological spread has increased, reaching a high mark of 2.033 in the 2010 s. The Portuguese party system has moved leftwards during the 1990s and then reverted to more moderate attitudes on the level of state involvement in the economy, only to increase its positive stance towards economic interventionism from the 2000s (median -1.748) to 2010s (-2.218). However, the difference in the stateconomy scale between these two decades was not statistically significant. Therefore, one can conclude that despite harsh austerity measures taken by South European governments during and immediately after the sovereign debt crisis, the basic orientation of these party systems towards left-wing, interventionist approaches to economic policy has not been altered. The only notable exception is Greece, where the party system has shifted, in terms of economic policy, closer to the ideological center (zero values on the stateconomy scale). The statistical strength of this effect was moderate $(r=0.33)$.

\section{Welfare State Policy / Politika socijalne države}

Regarding changes in attitudes towards welfare state policy, whereby more positive values denote less support for welfare state spending, while more negative values stand for more support for welfare state spending, the systemic level for the region shows no changes between the 2000s and 2010 s period, with welfare state policy 
firmly rooted on the left-hand side of the spectrum (more welfare state spending). The analysis of welfare state policy attitudes of the four major party families has also yielded no significant changes. Finally, the results for the country, i.e., party system level show that for none of the four analyzed country a statistically significant change between 2000s and 2010s in the median values of the stateservices scale could be detected. In addition, we could observe that for all four cases, the median values have been firmly on the left-wing side of scale (more negative values, more support for welfare state spending). For Italy, we could see an increase in the ideological spread during the 1990s, with further contraction in the later decades. The most ideological congruence (low ideological spread, measured with the help of the interquartile range) could be detected in the Spanish party system. Therefore, one can conclude that the European sovereign debt crisis did not reflect itself in party system attitudes on the desirable level of state spending on welfare state programs, i.e., the crisis did not significantly shift welfare policies.

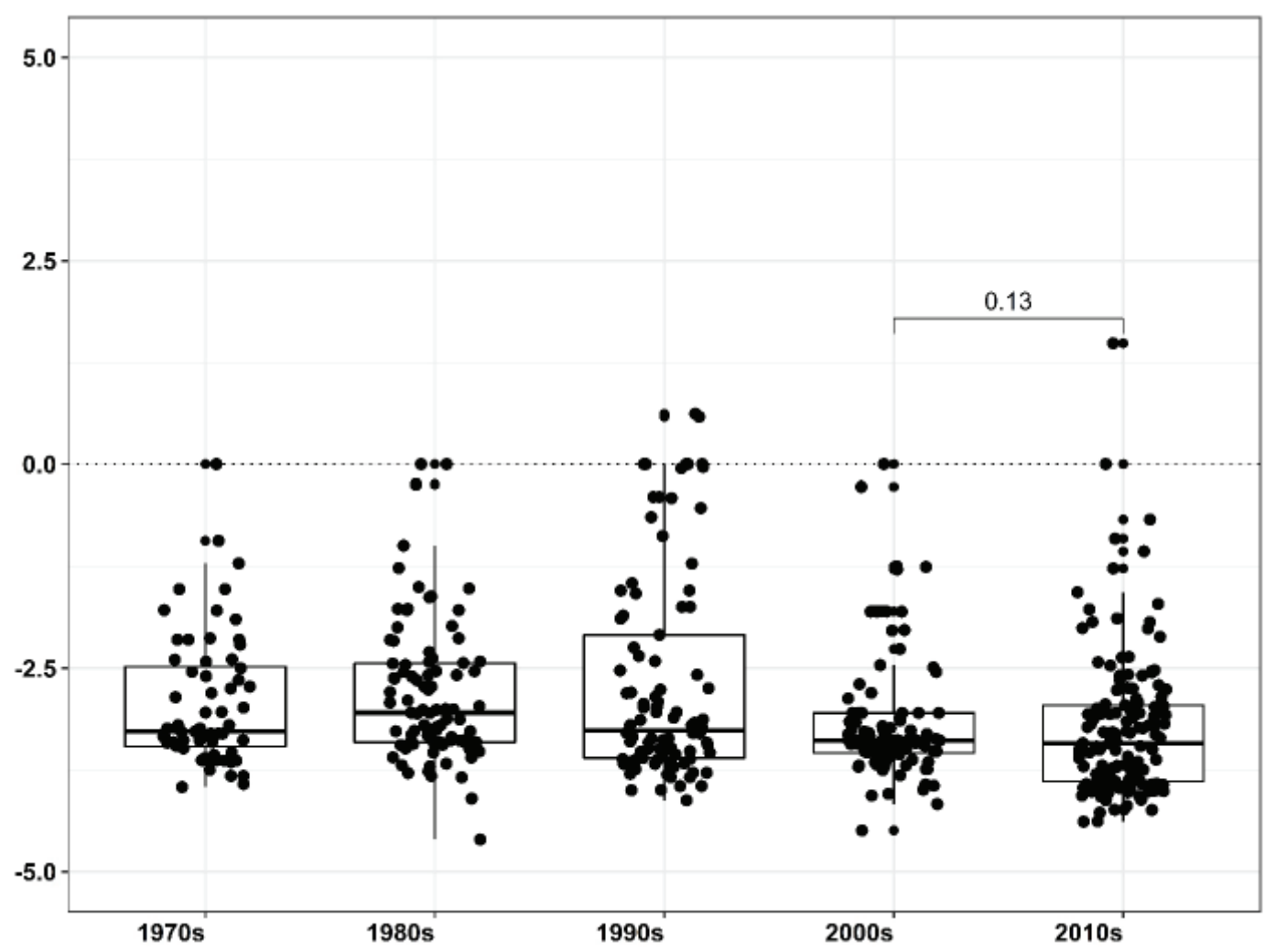

Figure 10. Welfare State Policy, Southern Europe / Slika 10. Politika socijalne države, Južna Europa 

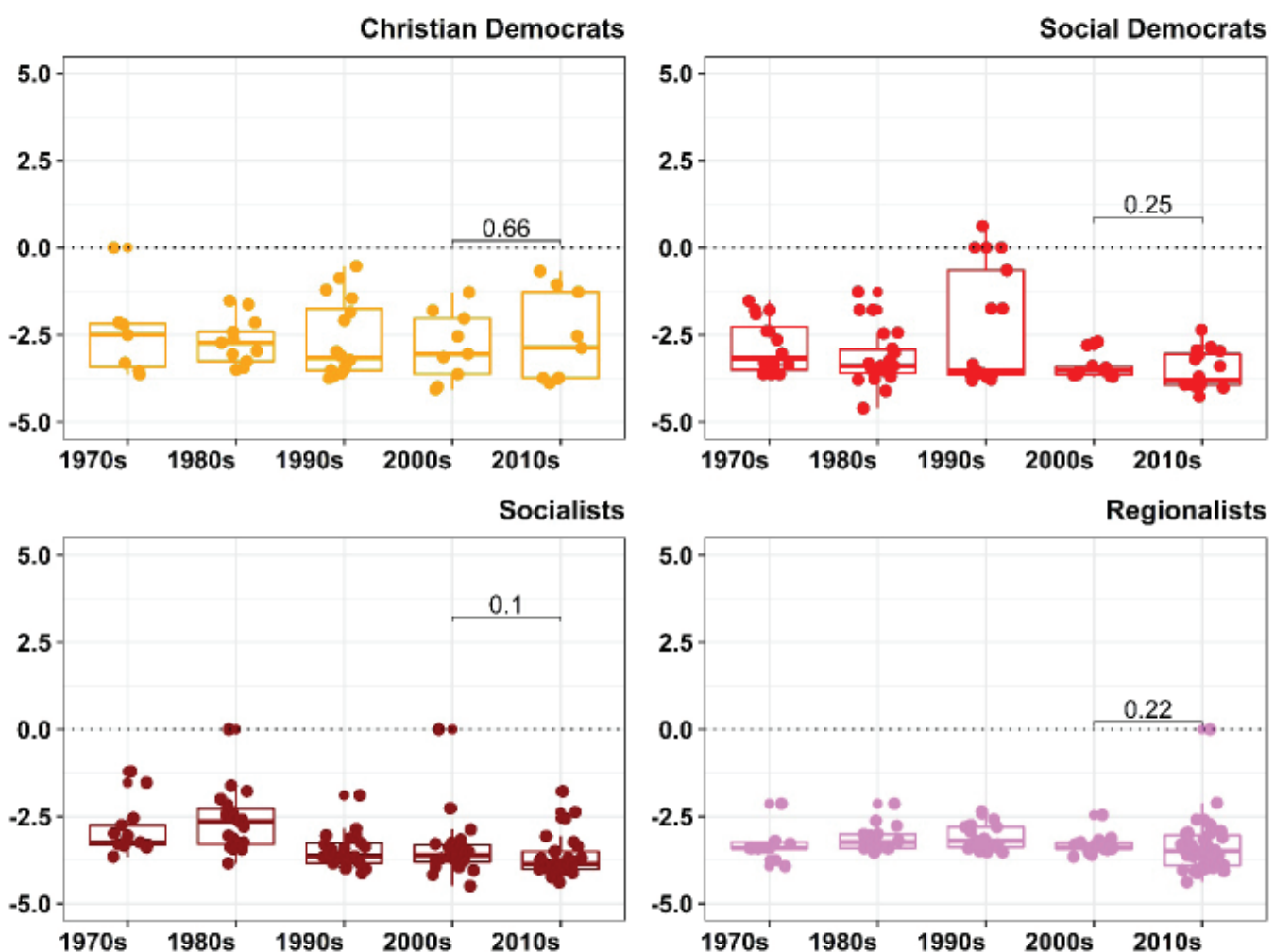

Figure 11. Welfare State Policy of Major Party Families, Southern Europe / Slika 11. Politika socijalne države velikih stranačkih obitelji, Južna Europa
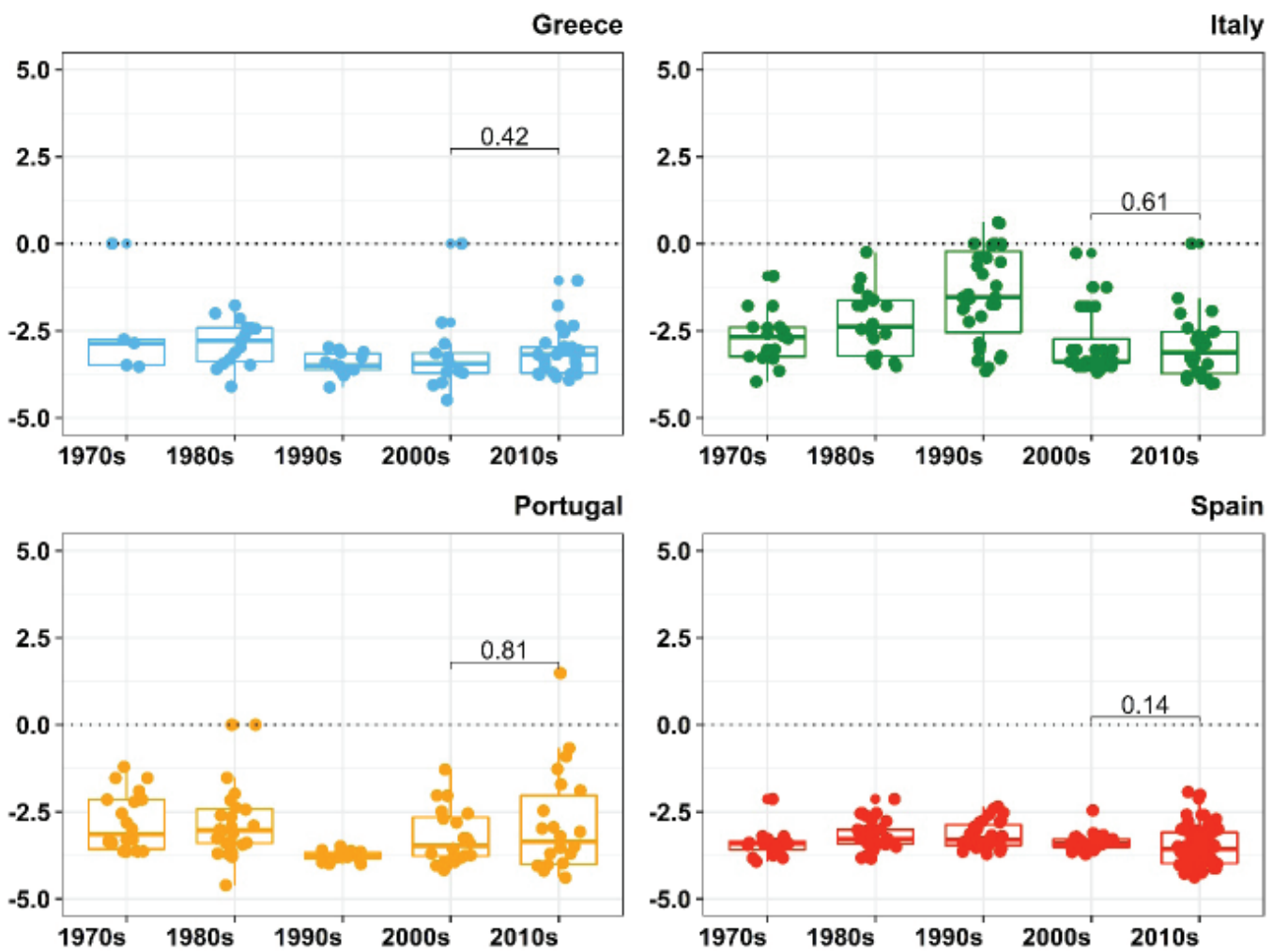

Figure 12. Welfare State Policy by Country, Southern Europe / Slika 12. Politika socijalne države po zemljama, Južna Europa 


\section{Conclusion / Zaključak}

The European sovereign debt crisis has had a profound impact on a whole generation in Southern Europe, cutting jobs and social transfers, and creating anger, despair, and resentment. The crisis reshaped party systems with the introduction of new, challenger parties or enabled once fringe parties to enter the mainstream, including cabinet positions. However, once the dust has settled, a trend of policy reversal could be observed.

In this paper, we tried to determine whether there were some substantial policy changes on party system level between the 2000s and the 2010s. This research question was tackled through three dimensions: overall regional stance, the stance of the four most prominent party families in the dataset for the region (Christian Democrats, Social Democrats, Socialists, and Regionalists), and the stance for the four countries, i.e. party systems.

Regarding the attitude towards the European Union, there was a small change towards less pro-EU stances on the level of the whole region. The party family dimension did not show any changes, while the only individual party system that saw minor movement towards less pro-EU stances was the Italian one. The overall ideological position of Southern European party systems shifted somewhat to the left, yet the effect of this change was small. This shift was primarily due to the more left-wing move of socialist parties, which moved to the left from 2000s to 2010s with a moderately strong effect. In addition, a leftward move was observed for the Spanish party system, yet, again, the statistical strength of the effect of this change was small. The economic policy, measured as the attitude towards state involvement in the economy, did not change on the regional level, nor did the four most prominent party families experience any significant movement. However, in Greece, the external pressure to change might have had somewhat of an impact, as its political system has, with moderate effect, moved towards less favorable attitudes towards state involvement in the economy. Regarding welfare policy, Southern European party systems did not experience meaningful change from the pre-crisis to the post-crisis period. Firmly favorable attitudes towards welfare state spending remained constant both on the regional level, as well as on the levels of prominent party families, and individual party systems.

Finally, we can conclude that party system data, measured with the help of electoral manifestos (CMP/MARPOR database), points out to more policy continuity than change in Southern Europe, a region socially and economically heavily affected by the sovereign debt crisis in the European Union. The rise of Euroscepticism, described in literature on Southern Europe during and after the Eurocrisis, could not be confirmed by this study on a systemic level. In addition, rather than moving to the center, the region moved slightly further to the left, with Spain leading this weak yet observable trend. Economic and welfare state policies, besides more centrist attitudes in economic policy in the Greek party system, also stayed constant.

Thus, this paper could not confirm a significant policy shift in Southern Europe after the "perfect storm" of the Eurocrisis. However, the implications of these findings should be interpreted in the light of official policy (measured through party manifestos), and not of actually pursued policy (in terms of votes for parliamentary bills and/or government policy). Nevertheless, the results of this analysis do support previous research about policy reversal and no political turnaround in Southern Europe. 


\section{References / Bibliografija}

Alexandre, Afonso; Bulfone, Fabio (2019). “Electoral Coalitions and Policy Reversals in Portugal and Italy in the Aftermath of the Eurozone Crisis". South European Society and Politics, Vol. 24, No. 2, pp. 233-257. https://doi.org/10.1080/13608746.2019.1644809

Antentas, Josep Maria (2017). "Spain: from the indignados rebellion to regime crisis (2011-2016)". Labor History, Vol. 58, No. 1, pp. 106-131. https://doi.org/10.1080/002365 6X.2016.1239875

Balampanidis, Ioannis; Vlastaris, Ioannis; Xezonakis, George; Magdalini, Karagkiozoglou (2019). "'Bridges Over Troubled Waters'? The Competitive Symbiosis of Social Democracy and Radical Left in Crisis-Ridden Southern Europe". Government and Opposition, Vol. 56, No. 1, pp. 59-81. https://doi.org/10.1017/gov.2019.8

Benoit, Kenneth; Laver, Michael (2007). "Estimating party policy positions: Comparing expert surveys and hand-coded content analysis". Electoral Studies, Vol. 26, No. 1, pp. 90-107. https://doi.org/10.1016/j.electstud.2006.04.008

Bosco, Anna; Verney, Susannah (2012). "Electoral Epidemic: The Political Cost of Economic Crisis in Southern Europe". South European Society and Politics, Vol. 17, No. 2, pp. 129-154. https://doi.org/10.1080/13608746.2012.747272

Bosco, Anna; Verney, Susannah (2016). "From Electoral Epidemic to Government Epidemic: The Next Level of the Crisis in Southern Europe". South European Society and Politics, Vol. 21, No. 4, pp. 383-406. https://doi.org/10.1080/13608746.2017.1303866

Branco, Rui; Cardoso, Daniel; Guillén, Ana M.; Sacchi, Stefano; Balbona, David Luque (2019). "Here to Stay? Reversals of Structural Reforms in Southern Europe as the Crisis Wanes". South European Society and Politics, Vol. 24, No. 2, pp. 205-232. https://doi.org/10.1080/13 608746.2019.1640966

Clements, Ben; Nanou, Kyriaki; Verney, Susannah (2014). "'We No Longer Love You, But We Don't Want to Leave You': The Eurozone Crisis and Popular Euroscepticism in Greece". Journal of European Integration, Vol. 36, No. 3, pp. 247-265. https://doi.org/10.1080/070363 37.2014.885753

Conti, Nicolò; Marangoni, Francesco; Verzichelli, Luca (2020). "Euroscepticism in Italy from the Onset of the Crisis: Tired of Europe?". South European Society and Politics, pp. 1-27. DOI: https://doi.org/10.1080/13608746.2020.1757885

Dinas, Elias; Gemenis, Kostas (2010). “Measuring Parties' Ideological Positions with Manifesto Data: A Critical Evaluation of the Competing Methods". Party Politics, Vol. 16, No. 4, pp. 427450. https://doi.org/10.1177/1354068809343107

Döring, Holger; Manow, Philip (2021). Parliaments and governments database (ParlGov): Information on parties, elections and cabinets in modern democracies. Development version. Available at: https://www.parlgov.org/about/ [accessed: 1/6/2021]

Fernandes, Jorge M.; Magalhães, Pedro C.; Santana-Pereira, José (2018). “Portugal's Leftist Government: From Sick Man to Poster Boy?". South European Society and Politics, Vol. 23, No. 4, pp. 503-524. https://doi.org/10.1080/13608746.2018.1525914

Freire, André; Lisi, Marco; Andreadis, loannis; Leite Viegas, José Manuel (2014). "Political Representation in Bailed-out Southern Europe: Greece and Portugal Compared". South European Society and Politics, Vol. 19, No. 4, pp. 413-433. https://doi.org/10.1080/13608746 .2014.984381

Freire, André; Teperoglou, Eftichia; Moury, Catherine (2014). "Awakening the Sleeping Giant in Greece and Portugal? Elites' and Voters' Attitudes towards EU Integration in Difficult Economic Times". South European Society and Politics, Vol. 19, No. 4, pp. 477-499. https:// doi.org/10.1080/13608746.2014.983311

Giannetti, Daniela; Pedrazzani, Andrea; Pinto, Luca (2017). "Party System Change in Italy: Politicising the EU and the Rise of Eccentric Parties". South European Society and Politics, Vol. 22, No. 1, pp. 21-42. https://doi.org/10.1080/13608746.2016.1174470 
Laver, Michael; Budge, Ian (1992). Party Policy and Government Coalitions. New York: St. Martin's Press. https://doi.org/10.1007/978-1-349-22368-8

Lewandowski, Jirka (2016). Working with the manifestoR package. Available at: https:// cran.r-project.org/web/packages/manifestoR/vignettes/manifestoRworkflow.pdf [accessed: $1 / 6 / 2021]$

Linz, Juan J.; Stepan, Alfred (1996). Problems of Democratic Transition and Consolidation: Southern Europe, South America, and Post-Communist Europe. Baltimore, MD: Johns Hopkings University Press.

Lisi, Marco (2020). "All Quiet on the European Front? Assessing the Impact of the Great Recession on Euroscepticism in Portugal". South European Society and Politics. Available at: https://www.tandfonline.com/doi/abs/10.1080/13608746.2020.1797308 [accessed: 1/6/2021]

Lowe, Will; Benoit, Kenneth; Mikhaylov, Slava; Laver, Michael (2011). "Scaling Policy Preferences from Coded Political Texts". Legislative Studies Quarterly, Vol. 36, No. 1, pp. $123-$ 155. https://doi.org/10.1111/j.1939-9162.2010.00006.x

MIDEM (2020). Emigration in Europa. Jahresbericht 2020. Dresden: Mercator Forum Migration und Demokratie (MIDEM), TU Dresden.

Müller, Jan-Werner (2012). “Europe's Perfect Storm: The Political and Economic Consequences of the Eurocrisis". Dissent, Vol. 59, No. 4, pp. 47-53. https://doi.org/10.1353/dss.2012.0089

Perez, Sofia A.; Matsaganis, Manos (2018). "The Political Economy of Austerity in Southern Europe". New Political Economy, Vol. 23, No. 2, pp. 192-207. https://doi.org/10.1080/135634 67.2017.1370445

Real-Dato, José; Sojka, Aleksandra (2020). "The Rise of (Faulty) Euroscepticism? The Impact of a Decade of Crises in Spain". South European Society and Politics. DOI: https://doi.org/10.10 80/13608746.2020.1771876

Schäfer, Constantin; Popa, Sebastian A.; Braun, Daniela; Schmitt, Hermann (2021). "The reshaping of political conflict over Europe: from pre-Maastricht to post-'Euro crisis"'. West European Politics, Vol. 44, No. 3, pp. 531-557. https://doi.org/10.1080/01402382.2019.1709754 Teperoglou, Eftichia; Belchior, Ana Maria (2020). “Is ‘Old Southern Europe' Still Eurosceptic? Determinants of Mass Attitudes before, during and after the Eurozone Crisis". South European Society and Politics. https://doi.org/10.1080/13608746.2020.1805878

Vesan, Patrik; Ronchi, Stefano (2019). "The Puzzle of Expansionary Welfare Reforms under Harsh Austerity: Explaining the Italian Case". South European Society and Politics, Vol. 24, No. 3, pp. 371-395. https://doi.org/10.1080/13608746.2019.1644811

Volkens, Andrea; Burst, Tobias; Krause, Werner; Lehmann, Pola; Matthieß, Theres; Merz, Nicolas; Regel, Sven; Weßels, Bernhard; Zehnter, Lisa (2020a). The Manifesto Data Collection. Manifesto Project (MRG/CMP/MARPOR). Version 2020b. Berlin: Wissenschaftszentrum Berlin für Sozialforschung (WZB). Available at: https://manifesto-project.wzb.eu/datasets/ MPDS2020b [accessed: 1/6/2021]

Volkens, Andrea; Burst, Tobias; Krause, Werner; Lehmann, Pola; Matthieß, Theres; Merz, Nicolas; Regel, Sven; Weßels, Bernhard; Zehnter, Lisa (2020b) The Manifesto Project Dataset - Codebook. Manifesto Project (MRG/CMP/MARPOR). Version 2020b. Berlin: Wissenschaftszentrum Berlin für Sozialforschung (WZB). Available at: https://manifestoproject.wzb.eu/down/data/2020a/codebooks/codebook_MPDataset_MPDS2020a.pdf [accessed: 1/6/2021]

Zamora-Kapoor, Anna; Coller, Xavier (2014). "The Effects of the Crisis: Why Southern Europe?". American Behavioral Scientist, Vol. 58, No. 12, pp. 1511-1516. https://doi. org/10.1177/0002764214530649 


\section{Appendix / Dodatak}

Table 2. Logit EU Descriptive Statistics / Tablica 2. LOGIT EU deskriptivna statistika

\begin{tabular}{lcccccc} 
Country & Decade & $\mathrm{N}$ & Min & Max & Median & IQR \\
Greece & $2000 \mathrm{~s}$ & 13 & -1.368 & 2.57 & 0 & 2.09 \\
\hline Greece & $2010 \mathrm{~s}$ & 28 & -2.916 & 3.695 & -0.082 & 1.879 \\
\hline Italy & $2000 \mathrm{~s}$ & 35 & -2.407 & 0.887 & -1.105 & 1.731 \\
\hline Italy & $2010 \mathrm{~s}$ & 24 & -3.2 & 2.435 & -0.172 & 2.595 \\
\hline Portugal & $2000 \mathrm{~s}$ & 20 & -1.732 & 1.795 & 0 & 2.107 \\
\hline Portugal & $2010 \mathrm{~s}$ & 22 & -1.676 & 2.833 & 0.154 & 2.248 \\
\hline Spain & $2000 \mathrm{~s}$ & 23 & -2.056 & 1.308 & -0.899 & 1.569 \\
\hline Spain & $2010 \mathrm{~s}$ & 68 & -2.281 & 2.12 & -0.643 & 1.33 \\
\hline
\end{tabular}

Table 3. Logit RILE Descriptive Statistics / Tablica 3. Logit RILE deskriptivna statistika

\begin{tabular}{lcccccc} 
Country & Decade & $\mathrm{N}$ & Min & Max & Median & IQR \\
Greece & $2000 \mathrm{~s}$ & 13 & -1.524 & 4.575 & -0.596 & 1.02 \\
\hline Greece & $2010 \mathrm{~s}$ & 28 & -1.578 & 1.299 & -0.268 & 1.473 \\
\hline Italy & $2000 \mathrm{~s}$ & 35 & -2.007 & 1.68 & -0.383 & 2.087 \\
\hline Italy & $2010 \mathrm{~s}$ & 24 & -2.197 & 1.099 & -0.034 & 0.815 \\
\hline Portugal & $2000 \mathrm{~s}$ & 20 & -2.88 & 0.673 & -0.649 & 1.24 \\
\hline Portugal & $2010 \mathrm{~s}$ & 22 & -2.171 & 1.736 & -0.705 & 1.288 \\
\hline Spain & $2000 \mathrm{~s}$ & 23 & -1.417 & 0.42 & -0.587 & 0.797 \\
\hline Spain & $2010 \mathrm{~s}$ & 68 & -2.567 & 1.122 & -1.14 & 1.143 \\
\hline
\end{tabular}

Table 4. Stateconomy Descriptive Statistics / Tablica 4. Gospodarstvo deskriptivna statistika

\begin{tabular}{lcccccc} 
Country & Decade & $\mathrm{N}$ & Min & Max & Median & IQR \\
Greece & $2000 \mathrm{~s}$ & 13 & -4.179 & 0 & -2.137 & 1.587 \\
\hline Greece & $2010 \mathrm{~s}$ & 28 & -4.416 & 0.473 & -0.951 & 1.567 \\
\hline Italy & $2000 \mathrm{~s}$ & 35 & -2.551 & 0.635 & -0.908 & 1.817 \\
\hline Italy & $2010 \mathrm{~s}$ & 24 & -3.621 & 0.432 & -0.879 & 2.033 \\
\hline Portugal & $2000 \mathrm{~s}$ & 20 & -3.604 & -0.082 & -1.748 & 1.824 \\
\hline Portugal & $2010 \mathrm{~s}$ & 22 & -3.773 & 1.685 & -2.218 & 2.561 \\
\hline Spain & $2000 \mathrm{~s}$ & 23 & -3.167 & -0.607 & -2.167 & 1.025 \\
\hline Spain & $2010 \mathrm{~s}$ & 68 & -4.318 & -0.213 & -1.899 & 1.734 \\
\hline
\end{tabular}

Table 5. Stateservices Descriptive Statistics / Tablica 5. Državne službe deskriptivna statistika

\begin{tabular}{lcccccc} 
Country & Decade & $\mathrm{N}$ & Min & Max & Median & IQR \\
Greece & $2000 \mathrm{~s}$ & 13 & -4.495 & 0 & -3.44 & 0.568 \\
\hline Greece & $2010 \mathrm{~s}$ & 28 & -3.917 & -1.062 & -3.187 & 0.741 \\
\hline Italy & $2000 \mathrm{~s}$ & 35 & -3.696 & -0.271 & -3.387 & 1.001 \\
\hline Italy & $2010 \mathrm{~s}$ & 24 & -4.017 & 0 & -3.12 & 1.193 \\
\hline Portugal & $2000 \mathrm{~s}$ & 20 & -4.17 & -1.284 & -3.472 & 1.109 \\
\hline Portugal & $2010 \mathrm{~s}$ & 22 & -4.016 & 1.485 & -3.348 & 1.973 \\
\hline Spain & $2000 \mathrm{~s}$ & 23 & -3.714 & -2.46 & -3.42 & 0.229 \\
\hline Spain & $2010 \mathrm{~s}$ & 68 & -4.382 & -1.93 & -3.561 & 0.887 \\
\hline
\end{tabular}




\section{Nakon oluje: stranački sustavi u Južnoj Europi nakon eurokrize}

Višeslav Raos

Sveučilište u Zagrebu E-mail:vraos@fpzg.hr
Izvorni znanstveni rad UDK 329(4-13)

DOI 10.17818/SM/2021/1.2

Rukopis primljen: 8. 6. 2021.

Rukopis prihvaćen: 14.12. 2021.

\section{Sažetak}

Zemlje Južne Europe godinama su se borile s posljedicama europske dužničke krize. Pod izvanjskim pritiskom provodile su oštre mjere štednje koje su za posljedicu imale poljuljano povjerenje u Europsku uniju, nove prosvjedne pokrete i ulazak novih političkih stranaka u zakonodavnu i potom izvršnu vlast. Desetljeće kasnije, ovaj rad postavlja pitanje je li oluja europske dužničke krize ostavila trajan utjecaj na Grčku, Italiju, Portugal i Španjolsku. Rad se fokusira na promjene na makrorazini te analizira promjene stranačkih sustava s pomoću podataka iz baze CMP/MARPOR. Članak se bavi promjenama u odnosu prema Europskoj uniji, pozicioniranju na ljestvici lijevodesno (RILE), kao i ekonomskoj politici te politici države blagostanja. Analiza pokazuje blago smanjenje pozitivnog stava o EU-u u Italiji, umjereno snažno skretanje španjolskoga stranačkog sustava ulijevo, kao i umjereno smanjenje pozitivnog stava o ulozi države u ekonomiji u grčkom slučaju. Zaključno se može reći kako deset godina nakon europske dužničke krize nije moguće govoriti o drastičnim promjenama stranačkih sustava u Grčkoj, Italiji, Portugalu i Španjolskoj te kako izvanjski pritisak nije uspio utjecati na činjenicu da su južnoeuropski stranački sustavi općenito nagnuti ulijevo.

Ključne riječi: Južna Europa, europska dužnička kriza, euroskepticizam, promjena javnih politika, izborni programi 